\title{
Performance Management Analysis of the Forum for Religious Harmony in Resolving Conflict and Maintaining Religious Harmony in South Tangerang City
}

\author{
${ }^{1}$ Slamet Suwanto, ${ }^{2} \mathrm{Ngadisah},{ }^{3}$ Nurliah Nurdin, ${ }^{4}$ Andi Pitono \\ 1,2,3,4 Institut Pemerintahan Dalam Negeri (IPDN), Indonesia \\ Email: slammas78@gmail.com
}

\begin{abstract}
This study aims to analyze the performance management of the Religious Harmony Forum, from now on referred to as FKUB, in maintaining interfaith harmony in the city of South Tangerang. This study used a qualitative approach with descriptive methods by conducting observations and interviews to collect data. In this study, it was found that FKUB South Tangerang City was not optimal in carrying out its functions and duties because it did not have good performance management. This can be seen from indicators, among others, there are still many people in South Tangerang City who do not know about the Tangsel FKUB and feel the benefits of the organization's existence, the Tangsel FKUB does not have a clear vision, mission and objectives, has not received adequate funding from the Tangsel City Government and has never carried out training for administrators. Therefore FKUB South Tangerang City needs to improve performance by using Armstrong performance management and Balance Scorecard (BSC).
\end{abstract}

Keywords: Harmony, Conflict, FKUB, Religion, Performance.

\section{A. INTRODUCTION}

Religion is a fundamental element in human life; therefore, religious freedom must be respected and guaranteed (Boyle \& Sheen, 1997). In this case, the state gives freedom to every citizen to adhere to the religion of his choice and to practice worship according to his belief. This is clearly and expressly stated in the 1945 Constitution article 29 paragraph (2) which reads: "The state guarantees the freedom of every citizen to embrace their respective religions and to worship according to their religion and belief."

It is a sociological fact that the Indonesian nation consists of a multicultural society which must be upheld, respected, and maintained continuously. It is precise because of this recognition of diversity that the Indonesian nation was formed. One form of diversity found in Indonesia is a religious issue. Indonesia is not a secular state, nor is it a religious state. Still, recognition of religion by the state only includes six religions, namely Islam, Hinduism, Buddhism, Christianity, Catholicism, and Confucianism. When viewed from the perspective of the guarantee of religious freedom contained in the constitution what is determined by this state is contradictory, because the state imposes restrictions by selecting a certain number of religions that can be embraced, in other words, religions other than those stipulated may not live in Indonesia. This is something paradoxical (Mustafa, 2006). 
Among the many conflicts in Indonesia, religious conflict has always been a hot issue. The Indonesian people, which are very diverse in ethnicity and religion, are a logical reason for the never-ending conflicts in this country (Ulya, 2016). Religious strife is very ironic because religion always teaches kindness, tolerance and mutual respect between humans. According to Ahmad (1994), several factors driving religion cause conflict, namely 1) Exclusivity of some religious leaders and adherents, 2) A closed attitude and mutual suspicion between religions, 3) Excessive linkages to religious symbols, 4) Religion which is the goal turned into a tool, and, 5) Political, social, and economic conditions.

Nicholson (1991) states that "Conflict resolution is the process facilitating a solution where the actors no longer feel the need to indulge in conflict activity and feel that the distribution of benefits in a social system is acceptable". When the conflicting parties feel that they no longer need to continue the conflict, conflict resolution becomes a facility for creating solutions. Conflict resolution is an effort to reduce or resolve conflict. Kriesberg (1997) defines conflict resolution as "conducting conflicts constructively, even creatively". This means minimizing violence resulting from conflict, overcoming hostility between conflicting parties, producing an acceptable outcome for the conflicting parties, and a sustainable solution.

Every citizen has the right to religion which is part of human rights and cannot be reduced under any circumstances (Bielefeldt, 2012). Likewise, every citizen has the freedom to choose a religion and worship according to his religion as well as the direction of government policies in national development in the field of religion, including improving the quality of services and understanding of religion, religious life, and increasing internal and inter-religious harmony. What was mentioned was among the primary considerations for the establishment of FKUB, as stated in PBM No. 09 \& 08 of 2006. On this basis, we know how urgent the FKUB's existence is in religious life in Indonesia.

Tangerang Selatan City is one of the municipalities included in the Banten Province which was officially established on November 26, 2008. As we all know that currently in Banten Province there are 4 (four) Regencies and 4 (four) Municipalities. Banten itself is a new province which is a division of the previous West Java Province and was subsequently inaugurated on October 17, 2000. (https://id.m.wikipedia.org). The city of South Tangerang was ratified at the DPR RI Plenary Session on Wednesday, October 29, 2008, with the enactment of Law Number 51 of 2008, after going through a long struggle since 2000 through the discourse of the formation of Cipasera City.

South Tangerang City administratively consists of 7 districts and 54 villages. Tangerang Selatan City has the following administrative boundaries:

1. In the north, it is bordered by Kota Tangerang and DKI Jakarta.

2. Eastside is bordered by West Java Province (Depok City) and DKI Jakarta.

3. In the south, it is bordered by West Java Province (Bogor Regency) and Depok City.

4. Westside is bordered by Tangerang Regency. 
See Tangsel residents from their ethnic perspective. There are indigenous people from Betawi-Sundanese ethnicities, Javanese, Chinese, Batak, Flores, Madurese and others who live in this area. In various life, almost all official religions recognized by the government are in this city and have houses of worship here. Also, most of the areas are elite, and middle-class housing or complexes and the rest are villages. The existing diversity, on the one hand, also raises a concern about the occurrence of social conflicts in the community, especially those with religious nuances, more triggered explicitly by disputes over places of worship.

Potential challenges and conflicts in the construction of houses of worship are homework for the Tangsel FKUB, because internally the organization also has performance management problems with various indicators such as human resources factors for FKUB administrators, whether it is seen from a competency perspective, whether those elected to be FKUB members are people. Who is competent both in the knowledge, understanding and practice of his religion, including how the internal election mechanism of the religion is, not to mention whether the person concerned has sufficient commitment and time so that he can focus and concentrate on this big task, because of both field and based findings. In other research, there are still many FKUB administrators who are concurrently ASN.

Quoting the speech of the Minister of Religion Suryadharma Ali, that we all need to always pay attention to the development and dynamic movements of FKUB. Watch in this regard relates to the management, membership, programs and activities displayed by FKUB and is the essence of the real face of each FKUB, namely whether it is running according to expectations. From this reality, we hope that there will be an optimistic reflection that FKUB is moving towards a more dynamic, creative, and increasingly reflects the growing values of togetherness, humanity, concern for the great awakening of a nation.

\section{B. METHOD}

This study uses a qualitative research design using a descriptive method (Creswell \& Creswell, 2017), which is intended to describe or describe existing phenomena, both natural phenomena or phenomena that are human engineering. The choice of this approach is based on the consideration that the data to be sought is data that explains how the life of religious harmony in Tangsel City and how the Tangsel Religious Harmony Forum (FKUB) plays in maintaining religious harmony in its area and the implementation of the processes they have carried out to date.

According to Creswell, qualitative research means the process of exploring and understanding the meaning of individual and group behaviour, describing social problems or humanitarian problems. The format in this study aims to describe, summarize various conditions, various situations, or various social reality phenomena that exist in society, which is the object of research. This opinion is also not much different from that conveyed by Sugiyono (2017), explaining that the characteristic of qualitative research is that this research is carried out intensively, researchers participate for a long time in the field, note carefully what happens, carry 
out reflective analysis of various documents that found in the area and make detailed research reports.

\section{RESULT AND DISCUSSION}

\section{Performance Management (Armstrong) FKUB South Tangerang City}

To achieve organizational goals, the Tangsel FKUB should have carried out or improved its performance management. This is necessary so that the Tangsel FKUB can provide excellent service to customers (religious communities), increase the quality and quantity of programs and services carried out, increase the competence of the management and better organizational governance. Thus, the implementation of performance management provides not only personal benefits for FKUB administrators, or just organizations, but also offers excellent benefits for the community, because performance management integrates individual, leadership and organizational goals.

Performance management is essential to be implemented by the Tangsel FKUB because of its holistic nature, which is comprehensive that covers the entire scope of management which includes the formulation of objectives, planning, implementation, supervision, assessment, measurement, feedback and evaluation and improvement (Ratnasari \& Hartati, 2019). Also, performance management is sustainable. A process that is always ongoing, so that gradually the performance of individuals and organizations will continue to be improved for better results. In other words, performance management will provide a common understanding of goals, what is needed to improve performance and how those goals can be realized. As for the essential points of performance management by referring to the theory of Performance Management (Armstrong), which must be optimized by FKUB. Tangsel includes the following:

\section{Mission and Objectives of the Organization}

In the view of Armstrong (2009). that the mission and objectives of the organization are the culmination of the entire series of organizational activities and at the same time, the starting point of the organizational performance management process. The mission and strategic objectives are then used as a reference for the management level of the organization under it. The formulation of the mission and strategic objectives of the organization is aimed at ensuring that each subsequent activity must be in line with these objectives and are expected to contribute to achievement. Furthermore, according to Armstrong, that the characteristics of an organizational goal can be said to be fair, if it fulfills the following characteristics:

1. Consistency, which is where there is consistency between the values of the organization and the objectives of the departments within the organization.

2. Precise is that the goals of the organization are clearly stated, well-formulated, using positive words that do not lead to multiple interpretations. 
3. Challenging, setting organizational goals is quite a challenge to provide a stimulus that encourages the organization to perform high work standards to make it happen.

4. Measurable, that the objectives can be linked to performance measures, both quantitatively and qualitatively.

5. Achievable, that the goals of the organization can be reached by individuals with all their capacities in the organization, taking into account any obstacles that affect the achievement of purposes, such as lack of resources, lack of knowledge and experience, etc.

6. Agreed, in this case, the goal must be agreed upon by all components in the organization, both management (leadership) and individuals in the organization.

7. Time-related that the predetermined goals can be achieved within a predetermined period so that in this case, time becomes an indicator of organizational success or failure.

8. Teamwork-oriented that the goal of the organization must focus on teamwork to achieve organizational and individual achievements.

The primary reference, as well as the legal umbrella for FKUB throughout Indonesia, is that the main guideline for FKUB is the Joint Ministerial Regulation (PBM), the Minister of Religion Number: 9 and the Minister of Home Affairs Number: 8 of 2006, concerning Guidelines for Implementing the Duties of Regional Heads/Deputy Regional Heads In Maintaining Religious Harmony, Empowering FKUB, and Establishing Houses of Worship, the background and considerations for their establishment do not differ from one region to another, of course including Tangsel. However, what is meant by the objectives of the FKUB, in this case, is what form of elaboration of PBM No. 09 and 08 of 2006 which is adapted to regional conditions and the resources of the Tangsel FKUB to become a working vision, and in reality the Tangsel FKUB during these two stewardship periods has not had a working vision, which is apparent as the implementation of PBM No. 09 and 08 of 2006.

\section{Planning}

Strategic planning in the view of Wibowo (2013) is a process of formulating, implementing and evaluating decisions that enable the organization to achieve its goals. Besides that, planning is designing what activities must be done to achieve organizational goals. In this case, planning also concerns how to provide the necessary resources and when it must be done so that organizational goals can be reached as expected. It was further explained that currently, there are three assumptions about strategic planning that are applied by many organizations in the world, namely:

1. Strategic planning is deliberate, meaning that the organization is making strategic plans; they are making decisions with full awareness. 
2. Strategic planning occurs when current targets can no longer be met, so a new strategy needs to be formulated.

3. New organizational goals require a new strategic plan if the organization is moving towards an entirely new direction and new goals so that a new strategic plan must be created.

The firm opinion was conveyed by Ida Ketut Ananta, who in this organization served as Deputy Chairperson of the Tangsel FKUB, stated that as an organization, the Tangsel FKUB had not yet been implemented, because it had not implemented management principles as an organization. Not only at the technical level, through unplanned board meetings, let alone major issues that include the vision and mission that become the targets and goals to be achieved in each period, completely absent and never discussed.

Therefore, to make improvements to the performance management of the Tangsel FKUB, there must be severe steps to improve the internal side of the organization by implementing management principles, in this case, planning. With clear and good planning, of course, it will make the organization run well.

\section{Performance Agreements}

A performance contract or agreement is simply a performance contract between an individual and a leader which is a representation of an organization. In this case, the two of them must obtain an agreement about the goals and objectives to be achieved by the organization and commitment in carrying out the contract in question. This performance agreement is essential not only as a basis for performance appraisal but also as a standard reference regarding the rights and obligations and responsibilities that must be carried out by all.

Following PBM Number 09 and 08 of 2006, the Forum for Religious Harmony, from now on abbreviated as FKUB, is a forum formed by the community and facilitated by the government to build, maintain and empower religious communities for harmony and prosperity. This organization is not a profit-seeking profit organization but is a non-profit organization whose primary goal is to serve the community (religious communities). As a state-owned organization (funded by the APBD), who can join the FKUB organization must also follow the existing regulations, namely PBM No. 09 and 08 of 2006 in Article 10, which states that:

1. FKUB membership consists of local religious leaders.

2. The number of members of the provincial FKUB is at most 21 people, and the number of members of the regency/city FKUB is at most 17 people.

3. The membership composition of the provincial and regency / municipal FKUB as referred to in paragraph (2) shall be determined based on the ratio of the number of followers of local religions with the representation of at least 1 (one) person from each religion in the province and district/city.

4. FKUB is led by 1 (one) chairman, 2 (two) deputy chairmen, 1 (one) secretary, 1 (one) deputy secretary, who are elected by deliberation by the members. 
From the above regulations, it can be understood that the number of District / City FKUB Management is determined to be 17 people, with the criteria as existing official religious leaders who come from the local area. Tangsel FKUB administrators, as well as FKUB administrators in other regions, are appointed and inaugurated through a Decree of the Governor and Regent / Mayor with one management period of 5 years.

Seeing the challenging task that must be done by the Tangsel FKUB, with management resources (17 people) and coming from various religions and backgrounds of different religious organizations and social organizations, the Tangsel FKUB in particular needs to create a Recruitment Process Flow that has adequate competence, have sufficient time, and no less critical high loyalty with existing regulations.

However, in this case, the researcher includes a discussion of leadership. This discussion is essential as a work agreement for the Tangsel FKUB management, not only because FKUB is an organization in which leadership is a crucial element in it, but is that the 17 members of the Tangsel FKUB are representatives of the religious community in Tangsel, totaling not less than 1,6 million people. They are religious leaders, who are the leaders of their people.

\section{Leadership}

Leadership is the process of influencing others in the relationship between leaders and subordinates or with followers. Frigon \& Jackson (1996), stated that: "leadership is the art and science of getting others to perform and achieve the vision". The above opinion describes leadership as the art and science of the process of obtaining action from others and achieving the vision. Every person or organization (including FKUB Tangsel) of course wants a leader who has adequate competence, has a character of honesty, is visionary for the foresight, provides inspiration to his followers, and can be a role model, including successfully realizing organizational goals. More than that, that a leader must know and be able to create an atmosphere of mutual trust in the organization, between leaders and subordinates, and vice versa. In short, a leader must be able to show high integrity and have significant meaning in the task at hand and be able to build trust to strive to achieve organizational goals jointly.

According to Pierce and Newstrom (2006), it includes: (1) A leader is a person who directs followers to produce performance/activity, (2) followers are people who work under the influence of the leader, (3) context is a situation (formal or informal, social or work, dynamic or static, emergency or routine, complex or straightforward according to the relationship between leaders and followers), (4) the process is an act of leadership, a combination of leading, following, guidance towards achieving goals, exchanging, building relationships, and (5) results are what arises from the relationship between the leader, the followers and the situation (respect, satisfaction, product quality). 
Therefore, it is in the view of researchers that understanding or knowledge of leadership needs to be studied by the management of FKUB Tangsel, realizing how vital the leadership factor is in all organizations. According to Rifa'i and Fadhli, this study on leadership provides information about the types of behaviours of influential leaders. The action of these leaders can be categorized into two dimensions, namely the initiating structure and consideration. The institutional structure dimension describes the extent to which leaders define and organize group interactions to achieve organizational goals and the extent to which leaders collect their group activities. This dimension is associated with the efforts of leaders to achieve organizational goals. The consideration dimension describes the area to which the level of the working relationship between the leader and his subordinates, and the extent to which the leader pays attention to the social and emotional needs of subsidiaries such as the need for recognition, job satisfaction and appreciation that affect their performance in the organization.

In organizational leadership at the Tangsel FKUB, the board members feel the vital role of the leader in this organization. Apart from the competencies mentioned above, a leader's requirement that cannot be taken lightly is health. This health factor supports the duties of a leader in running the organization.

Thus it becomes clear that the work agreement in the Tangsel FKUB as a non-profit organization that is tasked with providing religious services to the community (religious people), of course, requires the management to have high sincerity and spaciousness because they do not get a salary; otherwise, it is needed. Commitment, loyalty and responsibility to duties as stated in PBM No. 09 and 08 of 2006.

\section{Action and Development}

In Armstrong's view, one of the most fundamental objectives of substantive performance management is to align individual goals and organizational goals. This means that everything that is done by every individual in the workplace (in an organization) must lead to different results for the achievement of organizational goals. This goal is well expressed by Fletcher (1993). He writes: 'The real concept of performance management is associated with an approach to creating a shared vision of individual and organizational goals, helping each employee understand and recognize their role in contributing to them, and thus, manage and improve the performance of both individuals and organizations.

In addition to the alignment of individual goals and organizational goals, as mentioned above, the concept of performance management also talks about the behavior of people or organizations and the results they achieve. In the context of FKUB Tangsel, this behaviour is, of course, all the attributes attached to individuals in the organization (FKUB administrators) and the result is the accumulation of organizational performance activities that have been carried out. Therefore, the homework for the Tangsel FKUB administrators is to change or improve behavior in the organization to change performance management to get good results. The point is how to alter concepts, abstractions, discourses into real action on the ground. 
The Tangsel FKUB must actively work in the community (religious communities) because following its duties this organization must be able to establish communication between religious communities, capture the aspirations of religious communities, or conduct socialization of religious policies from the City Government of Tangsel for the community as a whole, as well as the socialization of PBM No .09 and 08 of 2006 mainly concern the construction of houses of worship. Because this is a challenging task, the Tangsel FKUB must maintain good relations with all circles both with the government and society.

\section{Monitoring}

The monitoring process or in this case, the evaluation of organizational performance is a critical activity for the organization itself. In the view of Kreitner et al. (2002), explaining the performance evaluation of the organization is very important because it can be used for; performance feedback, identifying the strengths and weaknesses of individuals and organizations, documenting staffing and payroll decisions, assisting and identifying goals and evaluating objectives.

Not only that, because this performance management evaluation can be used for a much more comprehensive range of matters including assessment of the intended objectives, in this case, is the process of knowing whether the activities that have been carried out by the organization within a certain time measure can be achieved or not (Ruky, 2002). This is important to become a provision for the organization to analyze what factors cause it and then find a solution if organizational goals cannot be achieved. Likewise, with evaluation in planning, to see whether the results obtained are not following plans etc (Sopiah, 2008).

According to Armstrong, that high-performance results from appropriate behavior, especially discretionary behavior, and the effective use of resources, be it the knowledge, skills and competencies required. The evaluation process in performance management is to examine how the organization has achieved the results because this process provides the necessary information to consider what needs to be done to improve these results in the future.

It seems that there is still a long way to go about changing performance management for the Tangsel FKUB by reflecting on this evaluation model. The reality is that so far, there has never been an effort to evaluate and monitor an organization regularly to see and measure its performance. Therefore, it becomes commonplace if in the end many people (religious communities) in the city of Tangsel do not know about the Tangsel FKUB and its management and have not felt the benefits of its presence. One of the factors is that the monitoring process of the Tangsel FKUB organization is not running at all.

\section{Continuous Feedback}

According to Armstrong, performance management will build an organizational culture in which managers, individuals and groups are responsible for the continuous improvement of business processes and their skills, competencies, 
and contributions. The most essential and often recurring concept is the process of managing and developing performance standards. In this case, openness, honesty, positive attitude and two-way communication between supervisors and employees are needed throughout the year. Performance management is concerned with creating a culture in which organizational and individual learning and development is a continuous process.

Armstrong further explained that basically, performance management is a continuous and flexible process that involves managers and those they manage to act as partners in a framework that defines the best way they work together to achieve the required results. Performance management focuses on planning and improving future performance which serves as a continuous and evolutionary process, where performance increases over time; and provide a basis for regular and frequent dialogue between managers and individuals about performance and development needs. This is primarily concerned with individual performance but can also apply to teams. The focus is on development, although performance management is an important part of the reward system by providing feedback and recognition and identifying growth opportunities.

The implementation of continuous feedback has not been thought of by the Tangsel FKUB so far, because it requires a future vision that even goes beyond the period of management. His enthusiasm in continuous feedback is how to make a good system, work management that runs optimally and the point is to make inheritance for the next Tangsel FKUB management. After conducting in-depth research and studies related to this sustainability, the researcher is of the view that what is the reasoning and acting of the management of FKUB Tangsel in the current organizational scope it is still the same and does not change, it is unlikely that optimization of performance management will be possible, let alone sustainability and inheritance. How can change be created, when there is no meeting (meeting), there is no goal or work vision, no SOP, no planning, no program, no motivation, innovation and creativity, no management training to improve competence etc.

\section{Performance Management Analysis of the FKUB City of Tangsel Using the Balanced Scorecard Method}

An organization that is either profit / profit or non-profit oriented, is always formed and based on a common goal. This goal is the driving force and motivation for the organization in every activity. However, to realize the goals of the organization, good management is needed and without a good management process it is impossible for the organization to be able to achieve its goals. The simplest management process is to maximize and optimize the use of organizational resources through the functions of planning, organizing, actualizing, controlling (POAC).

The Forum for Religious Harmony (FKUB) is a non-profit organization initiated by the community and fully facilitated by the Government. As is usually an organization in realizing its goals, FKUB including FKUB Tangsel also has many 
problems that must be resolved or challenges that must be faced in order to realize organizational goals as regulated in PBM Number 09 and 08 of 2006, both internal and external problems and challenges as many discussed in the previous chapter. In this study, researchers used Kaplan \& Norton's Balance Scorecard (BSC) to analyze the performance management of the Tangsel FKUB. The application of the BSC which is used as a performance management analysis tool is very useful for the Tangsel FKUB as a non-profit organization, which is more oriented towards customer satisfaction (religious communities) in the city of South Tangerang.

The application of the Balance Scorecard (BSC) in optimizing the performance management of FKUB Tangsel, still uses 4 perspectives as an analytical tool which includes:

1. Religious Satisfaction Perspectives which include: service, quality of service, partnership (participation) of religious communities and the timeliness of policies implemented.

2. Funding Perspective: Program innovation, funding savings, program optimization and legal search for organizational funding.

3. Internal Process Flow Perspective: Secretariat, Data, Public Relations and Management Recruitment.

4. Training and Learning Perspective: fulfilling the current mission objectives of the organization and fulfilling the organizational mission objectives in the future

\section{Religious Satisfaction}

In implementing the Balance Scorecard (BSC) for the Tangsel FKUB, the perspective of religious satisfaction is the main goal that must be realized. Goals are what an organization hopes to achieve or realize within a certain period of time. Because FKUB is an institution whose products are religious policies, of course the users of the products are all religious people as customers. The model for the perspective of religious satisfaction with the Balance Scorecard for FKUB Tangsel which is also a non-profit organization can be seen in the following table:

Table 1 The Perspective of Religious Satisfaction

\begin{tabular}{|l|l|}
\hline \multicolumn{4}{|c|}{ The Perspective of Religious Satisfaction } \\
\hline Goal & \multicolumn{1}{|c|}{ Size } \\
\hline Service & $\begin{array}{l}\text { Responsiveness according to the expectations of religious } \\
\text { communities }\end{array}$ \\
\hline Quality & $\begin{array}{l}\text { The quality of the activities is in accordance with the } \\
\text { expectations of the people }\end{array}$ \\
\hline Partnership & $\begin{array}{l}\text { The quality of the activities is in accordance with the } \\
\text { expectations of the people }\end{array}$ \\
\hline On Time & Clarity and timeliness of activities as expected \\
\hline
\end{tabular}

Source: Researchers 


\section{Funding}

In carrying out its operational activities, FKUB certainly requires adequate and adequate funding, thus enabling the organization to run optimally and optimally. However, in reality, not all or even many district/municipal governments do not provide funding assistance to FKUB, let alone sufficient and adequate. This problem is also the reason why many FKUBs are stagnant in the sense that they do not carry out program activities which in the end are unknown to the public.

The importance of the funding factor in organizational operations, even including non-profit organizations (FKUB Tangsel) is also a major component in the analysis of the application of the Balance Scorecard (BSC). Analysis of the funding perspective of the Tangsel FKUB can be seen in the following table:

\section{Table 2 Funding Perspective}

\begin{tabular}{|l|ll|}
\hline \multicolumn{2}{|c|}{ Goal } & \multicolumn{1}{c|}{ Size } \\
\hline $\begin{array}{l}\text { Maximize Value at the Lowest } \\
\text { Price }\end{array}$ & Organizational Innovation in Programs \\
\hline Maximizing Savings & Related to Budget Allocation \\
\hline Maximazing Program & Consistency \\
\hline $\begin{array}{l}\text { Seek funding } \\
\text { Organizations Legally }\end{array}$ & $\begin{array}{l}\text { Welfare of the Management and the } \\
\text { Independence of the Organization }\end{array}$ \\
\hline
\end{tabular}

Source: Researchers

\section{Internal Process Flow}

Quoting Amstrong's opinion in Wibowo, he stated that performance management is a systematic process to improve organizational performance by developing individual performance and team performance. In addition, performance management is a system where the organization determines work objectives, considers work standards, provides and evaluates work, provides performance feedback, considers training and development needs and distributes rewards. In other words, Armstrong emphasizes performance management as a system to improve performance.

In implementing the Balance Scorecard (BSC) to optimize the performance management of FKUB Tangsel, the perspective of the organization's Internal Process is an important aspect as well as other aspects. The researcher processed the internal process in the Tangsel FKUB which included four important elements, namely: secretarial which included an office and administrative duties. Furthermore, data management includes data on religious communities, program data, community requests and complaints and other organizational data. Media and Information as a means of socialization as well as a means of feedback between the organization and the community (religious communities) and the last one is the future recruitment of the Tangsel FKUB Management by making candidate criteria relevant to the needs of 
the organization going forward. More details can be seen in the following table image:

Table 3 Internal Process Perspective

\begin{tabular}{|c|c|}
\hline \multicolumn{2}{|r|}{ Internal Process Perspective } \\
\hline Goal & Size \\
\hline Secretariat & $\begin{array}{l}\text { Internal process flow: meetings, correspondence, research, } \\
\text { collaboration etc. }\end{array}$ \\
\hline Data & $\begin{array}{l}\text { Data management: Religious people, incoming cases, } \\
\text { potential conflicts }\end{array}$ \\
\hline Public Relation & $\begin{array}{l}\text { Information media management as well as feedback with } \\
\text { religious communities }\end{array}$ \\
\hline Recruitment & $\begin{array}{l}\text { Making criteria for candidates for the management of the } \\
\text { Tangsel FKUB }\end{array}$ \\
\hline
\end{tabular}

Source: Researchers

\section{Learning and Growth}

As with other perspectives in the application of the BSC to optimize performance management for FKUB Tangsel, this learning and growth perspective is also very important to be analyzed. In the dynamics of community life that is moving and changing dynamically, requires organizations to be able to adjust themselves in an effort to achieve their goals. According to Kaplan \& Northon, many organizations underwent radical changes when building a Balance Scorecard (BSC).

The change mainly lies in the human resources in the organization who must be able to take on new roles and responsibilities, so that the goals of customer satisfaction and internal processes can be achieved. They must change, from simply responding to customer demand (passive), to proactively anticipating customer needs, and marketing a wider range of products and services to customers. Because the organization demands new roles and responsibilities to existing human resources, on the other hand the organization is also required to conduct training and re-learning to them.

Likewise with FKUB Tangsel, which in the application of the Balance Scorecard (BSC) makes customer satisfaction (religious communities) the main goal that must be achieved. The main goal will not be realized without being supported by organizational optimization from other perspectives, and one of them is the perspective of learning, training and growth for all the Management in it.

Referring to Kaplan \& Northon's view that if the organization has long-term goals (customer satisfaction), then a training perspective, this learning must be done to all human resources it has. The purpose of applying this perspective of training, learning and growth can be seen in the following table: 
Table 4 Learning and Growth Perspective

\begin{tabular}{|l|l|}
\hline \multicolumn{2}{|c|}{ Learning and Growth Perspective } \\
\hline \multicolumn{1}{|c|}{ Goal } & \multicolumn{1}{c|}{ Size } \\
\hline \multirow{2}{*}{ Fulfill present-day goals } & Optimization of self-competence \\
\cline { 2 - 2 } & Self-competence and continuous improvement \\
\hline \multirow{2}{*}{ Fulfill future goals } & Self-assessment \\
\cline { 2 - 2 } & Strategic planning and tactical competence \\
\hline
\end{tabular}

Source: Researchers

\section{CONCLUSION}

The Tangsel Religious Harmony Forum (FKUB) is a forum formed by the community and fully facilitated by the Tangsel City Government to build, maintain, and empower religious communities for harmony and prosperity in the city of Tangsel, in reality, it does not have good performance management so it is not optimal. In carrying out its duties. Performance management approach to Performance Management, Armstrong is very appropriate and relevant for measuring performance management at FKUB Tangsel. The efforts to optimize performance management at the Tangsel FKUB include objectives, planning, work agreements, work and development activities, monitoring, continuous feedback, community satisfaction, funding, internal processes and training.

\section{REFERENCES}

1. Ahmad, A. S. (1994). Kebijaksanaan dan Perencanaan Komunikasi. Ujung Pandang: Hasanuddin University Press.

2. Armstrong, M. (2009). Armstrong's Handbook of Performance Management: An Evidence-Based Guide to Delivering High Performance. Kogan Page Publishers.

3. Bielefeldt, H. (2012). Freedom of Religion or Belief-A Human Right under Pressure. Oxford Journal of Law and Religion, 1(1), 15-35.

4. Boyle, K., \& Sheen, J. (1997). Freedom of Religion and Belief: A World Report. Psychology Press.

5. Brata, R. A. (2016). Analisis Masalah Good Governance dan Pemerintahan Strategis. Jakarta: Pustaka Kemang.

6. Creswell, J. W., \& Creswell, J. D. (2017). Research Design: Qualitative, Quantitative, and Mixed Methods Approach. London: Sage publications.

7. Ekawarna, H. (2018). Manajemen Konflik dan Stres. Jakarta: Bumi Aksara.

8. Fletcher, C (1993) Appraisal: Routes to Improved Performance. London: Institute of Personnel Managemen.

9. Frigon, N. L., \& Jackson, H. K. (1996). The Leader: Developing the Skills \& Personal Qualities You Need to Lead Effectively. Amacom.

10. Kreitner, R., Kinicki, A., \& Buelens, M. (2002). Organizational Behaviour. London, UK: McGraw Hill. 
11. Kriesberg, L. (1997). The Development of the Conflict Resolution Field. Peacemaking in international conflict: Methods and techniques, 51.

12. Mustafa, M. D. (2006). Reorientasi Teologi Islam dalam Konteks Pluralisme Beragama. HUNAFA: Jurnal Studia Islamika, 3(2), 129-140.

13. Nicholson, M. (1991). Resolution: The Role of Rational Approaches and their Criticism. New Directions in Conflict Theory: Conflict Resolution and Conflict Transformation, 57.

14. Pierce, J. L., \& Newstrom, J. W. (2006). Leader and the Leadership Process.

15. Ratnasari, S. L., SE, M., \& Hartati, Y. (2019). Manajemen Kinerja dalam Organisasi. Penerbit Qiara Media.

16. Ruky, A. S. (2002). Sistem Manajemen Kinerja. Jakarta: Gramedia Pustaka Utama.

17. Siagian, S. P. (2017). Teori Pengembangan Organisasi. Bandung: Bumi Aksara.

18. Soeryanto, S. E. (2011). Penerapan Manajemen Kinerja dengan Pendekatan Balanced Scorecard dalam Meningkatkan Akuntabilitas Pengelolaan Perguruan Tinggi. Majalah Ilmiah UNIKOM.

19. Sopiah, D. (2008). Perilaku Organisasional. Yogyakarta: Andi.

20. Sugiyono. (2007). Memahami Penelitian Kualitatif. Bandung. Alfabeta.

21. Ulya, I. (2016). Pendidikan Islam Multikultural Sebagai Resolusi Konflik Agama di Indonesia. Fikrah, 4(1), 20-35.

22. Wibowo. (2013). Manajemen Kinerja. Depok: RajaGrafindo Persada.

23. Winarno, B. (2007). Kebijakan Publik: Teori dan Proses. Yogyakarta: Media Pressindo. 